Original Article

\title{
Molecular detection of Mycoplasma gallisepticum in different poultry breeds of Abbottabad and Rawalpindi, Pakistan
}

\author{
Detecção molecular de Mycoplasma gallisepticum em diferentes raças de aves de \\ Abbottabad e Rawalpindi, Paquistão
}

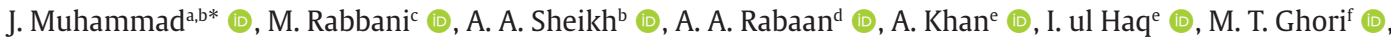 \\ S. A. Khan ${ }^{\mathrm{g}}$ (1) and A. Akbars* (1) \\ aThe University of Haripur, Department of Microbiology, Haripur, Pakistan \\ bUniversity of Veterinary and Animal Sciences, University Diagnostic Lab, Lahore, Pakistan \\ cUniversity of Veterinary and Animal Sciences, Department of Microbiology, Lahore, Pakistan \\ dohns Hopkins Aramco Healthcare, Molecular Diagnostic Laboratory, Dhahran, Saudi Arabia \\ eThe University of Haripur, Department of Public Health \& Nutrition, Haripur, Pakistan \\ 'The Islamia University of Bahawalpur, Department of Clinical Medicine and Surgery, Punjab, Pakistan \\ gUniversity of Balochistan, Department of Microbiology, Quetta, Balochistan, Pakistan
}

\begin{abstract}
The poultry sector in Pakistan is contributing mainly in bridging gap between demand and supply for protein. Mycoplasma gallisepticum is an emerging bacterium causing serious problems in poultry industry of Pakistan. A cross-sectional study was conducted to evaluate the M. gallisepticum load in poultry populated regions of Pakistan. Total 600 serum and 600 swab samples were collected, 200 from each broiler, layers and breeders poultry in Rawalpindi and Abbottabad districts. Serum samples were analyzed through ELISA for seroprevalence. Swabs were cultured on Frey's medium followed by PCR and partial $m g c 2$ gene sequencing. Results of seroprevalence of $M$. gallisepticum showed that layers $(75 \%, n=150)$ are more positive as compared to breeders $(70 \%, n=140)$ and broilers ( $50 \%, \mathrm{n}=100)$. Typical colonies of the $M$. gallisepticum were observed in breeder $(26.5 \%)$, followed by layer (21\%) and broilers (9\%). A total of $37.1 \%(n=42)$ samples were identified positive through PCR out of total 113 cultured based positive samples. A total of six M. gallisepticum isolates of current study showed 98-99 percent similarity with previously reported isolates on the basis of $m g c 2$ gene partial sequencing. The M. gallisepticum was found highly prevalent in different poultry breads. Results of this study would add into basic data and provide a direction for livestock sector to strengthen a control strategy for mycoplasmosis in poultry farms.
\end{abstract}

Keywords: mycoplasmosis, ELISA, $m g c 2$ gene, PCR, poultry.

\section{Resumo}

O setor avícola do Paquistão está contribuindo principalmente para preencher a lacuna entre a demanda e a oferta de proteína. Mycoplasma gallisepticum é uma bactéria emergente que causa sérios problemas na indústria avícola do Paquistão. Um estudo transversal foi conduzido para avaliar a carga de M. gallisepticum em regiões de avicultura do Paquistão. Um total de 600 amostras de soro e 600 amostras de esfregaço foi coletado, 200 de cada frango de corte, poedeiras e aves reprodutoras nos distritos de Rawalpindi e Abbottabad. Amostras de soro foram analisadas por ELISA para soroprevalência. As zaragatoas foram cultivadas em meio Frey, seguido de PCR e sequenciação parcial do gene mgc2. Os resultados da soroprevalência de $M$. gallisepticum mostraram que as poedeiras $(75 \%, n=150)$ são mais positivas em comparação com matrizes $(70 \%, n=140)$ e frangos de corte $(50 \%$, $\mathrm{n}=100)$. Colônias típicas de $M$. gallisepticum foram observadas em reprodutoras (26,5\%), seguidas de poedeiras (21\%) e frangos de corte (9\%). Um total de $37,1 \%(n=42)$ das amostras foi identificado como positivas por PCR de um total de 113 amostras positivas baseadas em cultura. Um total de seis isolados de M. gallisepticum do estudo atual mostrou 98-99\% de similaridade com isolados relatados anteriormente com base no sequenciamento parcial do gene mgc2. O M. gallisepticum foi encontrado com alta prevalência em diferentes pães de aves. Os resultados deste estudo acrescentariam dados básicos e forneceriam orientação para o setor pecuário fortalecer uma estratégia de controle da micoplasmose em granjas avícolas.

Palavras-chave: micoplasmose, ELISA, gene mgc2, PCR, aves.

*e-mail: aliakbar.uob@gmail.com; javedM81@hotmail.com

Received: December 12, 2020 - Accepted: January 27, 2021 


\section{Introduction}

Mycoplasma gallisepticum (M. gallisepticum) is causing mycoplasmosis and is considered as Chronic Respiratory Disease (CRD) in both chicken and turkeys (Osman et al., 2009). Clinical manifestation of the disease includes nasal and ocular discharge, coughing, abnormal feathers, poor productivity and moderate mortality (McMullin, 2004; Nascimento et al., 2005). Breaking the chain of transmission of M. gallisepticum further in poultry flocks is possible with implementing the strict biosecurity measures at individual farm level. It will help in controlling and preventing the CRD in poultry industry (Ferguson et al., 2005). Regional surveillance $M$. gallisepticum is very necessary because the data from genome sequencing of $M$. gallisepticum revealed that with passage of time new strain are evolving in the field which may hamper the success of vaccine and controlling the infection as well as detection in detection (Delaney et al., 2012; Ferguson et al., 2005). Further, there is need to develop vaccine and diagnostic antigens based on local isolates for effective management and eradication of mycoplasmosis in the poultry at country level. (Silva et al., 2021). In Pakistan, CRD is big issue and one of major reason of huge economic loss in poultry industry. The financial constrains facing by the farmers, only a few of them are using a vaccine to protect their poultry from $M$. gallisepticum with compromised results. The remaining are using only antibiotics for treatment of the infection which can ultimately develop antibiotic resistance in the field. Current study was designed to find the burden of local M. gallisepticum using ELISA, culturing based method and PCR in all breeds of poultry in two major districts Abbottabad and Rawalpindi of Pakistan.

\section{Materials and Methods}

A cross-sectional study was conducted in one of the most poultry populated districts of Pakistan, where large number of commercial farms are located. A conventional isolation method followed by PCR and ELISA method was used for comparative analysis and confirmation of M. gallisepticum. A partial sequencing of targeted mgc2 gene from local isolates was carried out to measure the similarity in the species. Total 600 serum and 600 swab samples were collected, 200 from each broiler, layers and breeders poultry in Rawalpindi and Abbottabad.

\subsection{ELISA test and culturing}

The serum samples were processed through ELISA (ProFLOK® Synbiotics, USA) to estimate the prevalence of $M$. gallisepticum antibodies. The traches swab samples were processed on commercially available Frey's medium (Part One: Mycoplasma broth base 5.62 gm, Thallium acetate $0.074 \mathrm{gm}$,, phenol red $0.0074 \mathrm{gm}$, yeast extracts 1.25 gm, distilled water, 200 mL; Part Two: Cysteine HCL 0.025 gm, Penicillin G 0.156 gm, horse serum 30 mL, glucose 0.074 gm, Nicotinamide Adenine Dinucleotide 0.025 gm, distilled water $20 \mathrm{~mL}$ ). Part one ingredients were adjusted to $250 \mathrm{~mL}$ with distilled and $\mathrm{pH} 7.8$ and autoclaved at $121^{\circ} \mathrm{C}$ temperature for $15 \mathrm{~min}$ at $15 \mathrm{psi}$ pressure. The part two containing temperature labile ingredients which were filtered from $0.2 \mu \mathrm{m}$ syringe filter and was added to part at part one at low temperature.

\subsection{Molecular detection}

All suspected positive samples showing fried egg-shaped colonies were processed though PCR for further confirmation. A DNA was extracted from samples with typical mycoplasma colonies using commercially available genome extraction QIAGEN kit (USA). A specie specific primers for identification of $M$. gallisepticum were used for amplification of partial gene of $m g c 2$ (Forward $m g c 2$ - 5'-GGTCCTAATCCCCAACAAAGAAT-3'; Reverse mgc2-5'-CTTGGTTGGTTCATA-TTAGGCATTT-3' (Grodio et al., 2008). Amplification of the gene was carried out in Thermocycler (BioRed CFX96, USA) with ready to use fermentas master mix (Thermo Scientific, USA) as per instructions of manufacturer. The thermocycler was set up on PCR condition as initial denaturation at $95^{\circ} \mathrm{C}$ for 5 mints, 35 cycles of $94{ }^{\circ} \mathrm{C}$ for $30 \mathrm{sec}, 55^{\circ} \mathrm{C}$ for $30 \mathrm{sec}$ and $72{ }^{\circ} \mathrm{C}$ for $30 \mathrm{sec}$ and then final extension at $72{ }^{\circ} \mathrm{C}$ for 5 minutes. Amplified PCR products were run on 2 percent agarose gel using Tris Boric acid EDTA buffer in gel electrophoresis assembly. A QIAquick Gel Extraction Kit (QIAGEN, USA) was used for extraction of positive PCR products for further sequencing and analysis. Two samples of PCR amplified products from each layer, broiler and breeder were selected for sequence analysis through ABI 3130XL Automated Sequencer (Applied Biosystem Inc, Foster city, CA). Sequence similarity was found using BLASTN analysis and $m g c 2$ gene partial sequences of local isolates were submitted to NCBI for accession number. All partial mgc2 gene sequences of local isolates were phylogenetically analyzed with globally reported mgc2 gene sequences through MEGA5 software using Bootstrap method and statistical test of Neighbor-joining with 1000-boostrap replicate (Tamura et al., 2011).

\subsection{Ethical consideration}

The Ethical Research Board in The University of Veterinary and Animal Sciences, Lahore approved the blood samples collected from poultry for analysis. All samples were collected using guidelines of International Animal Care and Use Committee (IACUC) with prior consent from farm's owner.

\subsection{Statistical analysis}

Results obtained from ELISA, cultured based test and PCR were analyzed using $\chi 2$ square test through Statistical Packages for the Social Sciences (SPSS) software version 26.0 (Priya and Madhavan, 2002).

\section{Results}

Out of total 600 serum collected, 200 from each broiler, layers and breeders, a reasonable number showed detectable level of serum anti-M. gallisepticum ELISA antibodies. The ELISA results showed that breeder breeds $75 \%(n=150)$ were more positive as compared to layers $70 \%$ 
( $\mathrm{n}=140)$ and broilers $50 \%(\mathrm{n}=100)$ broiler as shown in Table 1. In the tracheal swabs streaked on Frey's agar showed fried egg-shaped colonies which were suspected as Mycoplasma species. Samples $18.8 \%$ ( $n=113$ ) were found positive for M. gallisepticum on the basis of colony morphology. Typical colonies of the M. gallisepticum were observed in breeder (26.5\%), followed by layer (21\%) and broilers ( $9 \%$ ) as shown in Table 1 . A total of $37.1 \%(n=42)$ samples were identified positive through PCR out of total 113 cultured based positive samples (Figure 1). Identification of M. gallisepticum through PCR using primers against mgc2 gene showed that broiler flocks (50\%) were more positive as compared to breeder (37.7\%) and layer (30.9\%) as shown in Table 1. The sequences of partial $m g c 2$ gene of $M$. gallisepticum isolates in current study were compared with already reported and available sequences of the same gene on NCBI GenBank using nucleotide BLAST analysis. All sequences were processed through MEGA5 software using statistical test of Neighbor-Joining with 1000-boostrap replicates. The Phylogenetic tree represented that the sequences of M. gallisepticum from this study clustered with previously reported sequences of $m g c 2$ gene of this region as shown in Figure 2. A pairwise analysis of nucleotide sequences of currently characterized isolates showed 98 to 100 percent similarity with worldwide M. gallisepticum isolates and
98 to 99 percent similarity with previously reported isolated reported from Pakistan (Table 2). All sequences of isolated from this study are available at NCBI GenBank with accession numbers: KF874283, KF874282, KF874281, KF874280, KF874279, and KF874278.

\section{Discussion}

Previous studies showed that every test has its own specificity and sensitivity and results of all tests such as conventional isolation methods, spot agglutination test, ELISA, Haemagglutination inhibition test, and PCR provide variations (Feberwee et al., 2005; Luciano et al., 2011). These variations may be due to cross reactivity with other mycoplasma species, samples collected from birds with different age and improper sample transportation (Buchala et al., 2006). Diagnosis of Mycoplasma through conventional method of culturing is a "Gold Standard" but this technique is very laborious, expensive, time consuming due to slow growth and require very skilled staff. These things may lead to variations in results of conventional methods (Gharaibeh and Al Roussan, 2007; Khalifa et al., 2013). Results of current study from same samples showed similar variations in three tests (ELSA,

Table 1. Results of three different diagnostic techniques (ELISA, Culturing and PCR) for Mycoplasma gallisepticum.

\begin{tabular}{|c|c|c|c|c|c|c|c|c|c|c|c|c|}
\hline \multirow[b]{2}{*}{ Breed } & \multicolumn{4}{|c|}{ ELISA } & \multicolumn{4}{|c|}{ Tracheal swab Culturing } & \multicolumn{4}{|c|}{ PCR } \\
\hline & Total & +ve & -ve & $\begin{array}{c}\text { Prevalence } \\
\text { (\%) }\end{array}$ & Total & +ve & -ve & $\begin{array}{c}\text { Prevalence } \\
\text { (\%) }\end{array}$ & Total & +ve & -ve & $\begin{array}{c}\text { Prevalence } \\
\text { (\%) }\end{array}$ \\
\hline Broiler & 200 & 100 & 100 & 50 & 200 & 18 & 182 & 9 & 18 & 9 & 9 & 50 \\
\hline Breeder & 200 & 150 & 50 & 75 & 200 & 53 & 147 & 26.5 & 53 & 20 & 33 & 37.7 \\
\hline Layer & 200 & 140 & 60 & 70 & 200 & 42 & 158 & 21 & 42 & 13 & 29 & 30.9 \\
\hline Total & 600 & 390 & 210 & 65 & 600 & 113 & 487 & 18.8 & 113 & 42 & 71 & 37.1 \\
\hline
\end{tabular}

+ve: Positive, -ve: Negative.

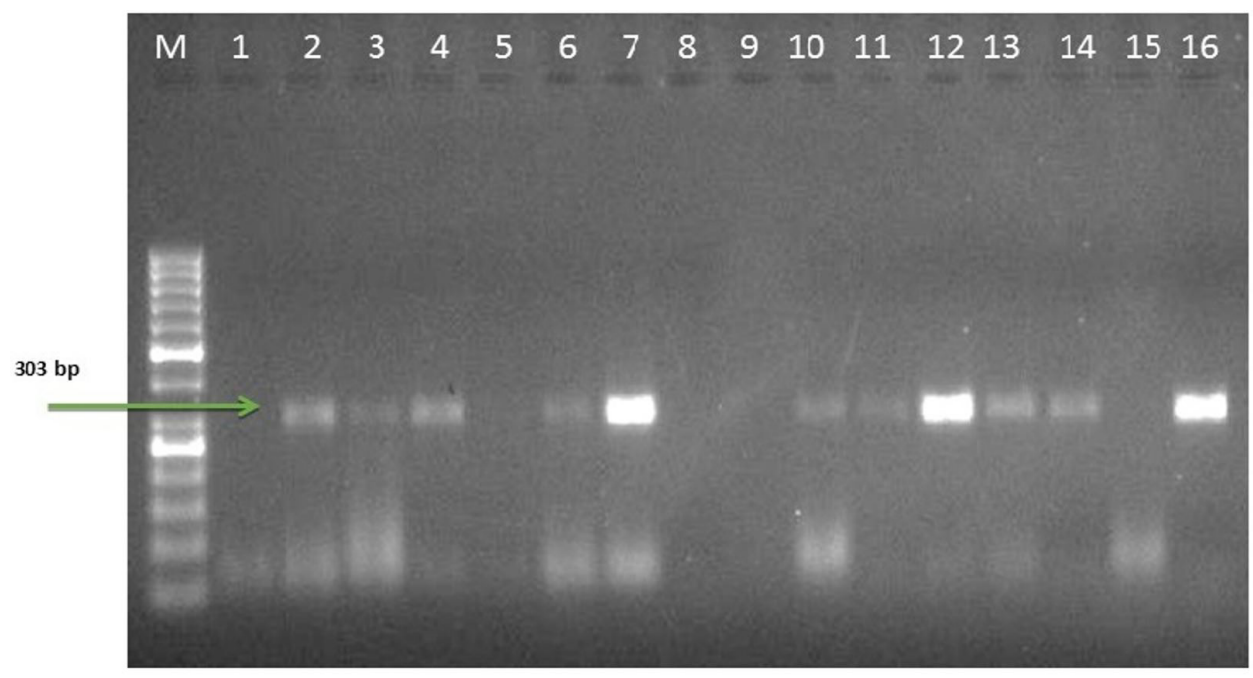

Figure 1. Agarose gel electrophoresis of PCR products of Mycoplasma gallisepticum (mgc2 gene); Lane M: DNA marker 50 bp, Lane 1: Negative control, Lane 2: Positive control (303bp), Lane 3, 4, 6, 7, 10-14, and 16: Mycoplasma gallisepticum positive isolates (303bp), Lane 5, 8, 9 and 15: Mycoplasma gallisepticum negative sample. 
culture, and PCR). Seroprevalence of anti- M. gallisepticum in all breeders, layers and broilers were found $75 \%$. While tracheal swabs from same birds showed $37.1 \%$ positivity through conventional method in terms of mycoplasma typical fried egg-shaped colonies. The swab tested through PCR showed $26.5 \%$ positivity for M. gallisepticum. High number of positivity through culturing as compared to PCR is due to growth of other mycoplasma species such

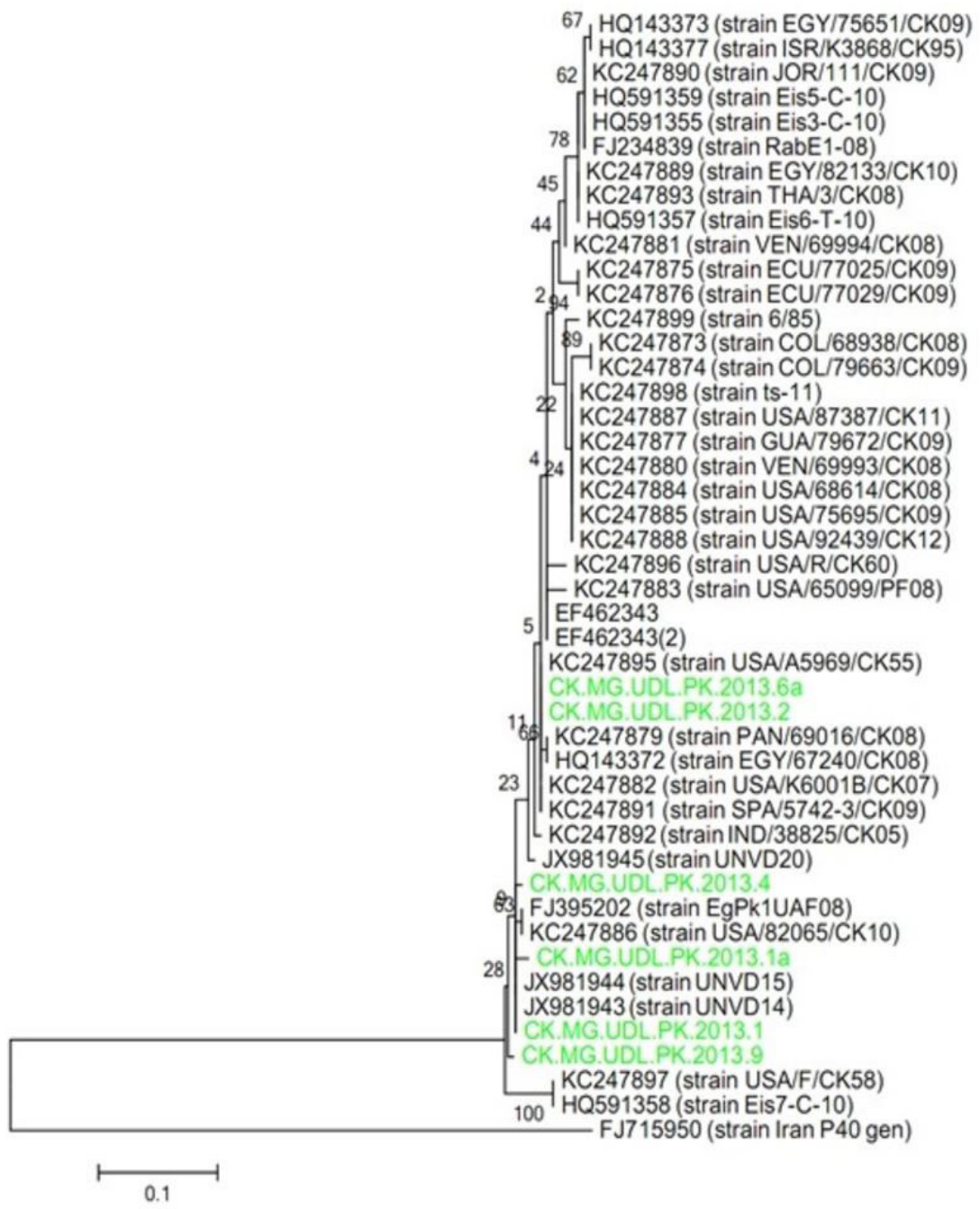

Figure 2. Partial mgc2 gene sequence analysis of Mycoplasma gallisepticum isolates from Pakistan by the Neighbor-joining method with 1000-Bootstrap replicates using MEGA5 software.

Table 2. Percentage identity of local isolates of Mycoplasma gallisepticum from Pakistan with reported isolates globally.

\begin{tabular}{|c|c|c|c|c|c|c|c|}
\hline \multirow{4}{*}{$\begin{array}{l}\text { International } \\
\text { Isolates }\end{array}$} & \multirow{4}{*}{ Origin } & \multicolumn{6}{|c|}{ Percentage identity of local isolates (Pakistan) } \\
\hline & & \multicolumn{6}{|c|}{ Source of Isolates } \\
\hline & & Layer & Layer & Breeder & Broiler & Breeder & Broiler \\
\hline & & KF874278 & KF874279 & KF874280 & KF874281 & KF874282 & KF874283 \\
\hline FJ395202 & Pakistan & 99 & 99 & 98 & 99 & 98 & 99 \\
\hline KC247895 & USA & 98 & 98 & 100 & 98 & 100 & 98 \\
\hline КС247879 & Panama & 97 & 98 & 99 & 98 & 99 & 98 \\
\hline КС247892 & India & 100 & 100 & 100 & 100 & 100 & 100 \\
\hline JX981945 & Egypt & 98 & 98 & 99 & 98 & 99 & 99 \\
\hline КС247891 & Spain & 98 & 98 & 100 & 98 & 100 & 98 \\
\hline
\end{tabular}


as M. synoviae. For diagnosis of M. gallisepticum, ELISA is the most common technique, but chances of non-specific reaction give false positive results and it might be the reason of high positivity in our results (Kleven, 2008; Much et al., 2002). During comparison between ELISA and culturing, breeder showed the highest positivity $75 \%, 26.5 \%$ followed by layers $70 \%, 21 \%$ and broiler $50 \%, 9 \%$, respectively as shown in Table 1. Diagnosis and control of M. gallisepticum on the basis of sero-conversion is not sufficient (Waites and Talkington, 2004). As per World Organization for Animal Health (OIE) standard, an alternative to culturing, the PCR is a test of choice for diagnosis of M. gallisepticum in poultry industry due to its high sensitivity and rapid diagnosis. Identification of $M$. gallisepticum through PCR using primers against mgc2 gene showed that broiler flocks (50\%) were more positive as compared to breeder (37.7\%) and layer (30.9\%). Similar results were found in previous studies (Marois et al., 2001). Mycoplasmosis is majorly present in breeder (27\%) which plays a significant role in vertical transmission through eggs from parents to progeny (Buim et al., 2009). In present study, high level of positivity in broiler (50\%) showed alarming situation because in broilers, the transmission is mainly horizontally due to transmission through aerosol and contaminated water, feed and environment. It might be also due to the ability of Mycoplasma to survive for long time on different fomites and remain major source of infection in new flock in absence of hygienic environment in the farm. Absence of good hygienic practices may be one of major reason high prevalence of $M$. gallisepticum in studied districts as compared to previous study (21.84\%) conducted in Pakistan (Rauf et al., 2013). Isolates and strains vary in their pathogenicity pattern with differentiation in phenotypic and genotypic characteristics (García et al., 2005). For in depth study of $M$. gallisepticum in a specific region to understand the epidemiological niche, transmission of diseases and finding of new track of outbreaks, there is need to adopt a most reliable technique for differentiation the specie in more detail (Loolmani et al., 2014). The $m g c 2$ gene targeted in this study is most specific, and sensitive and can be used as reference only for molecular based identification of M. gallisepticum (Youni et al., 2018; Emam et al., 2020). The particle sequencing and analysis of $m g c 2$ gene showed a 100 percent similarity of local isolates from this study with isolated reported from India. Further 98 to 99 percent similarity was found with isolates already reported from Pakistan, Panama, USA, Spain, and Egypt. Minor variation was found between isolates used in this study which showed heterogenetically different isolates are prevailing in Pakistan and same scenario is prevails in India. Mycoplasma gallisepticum isolates from Breeder showed $100 \%$ similarity with isolates from USA and Spain. Sequence analysis on the basis of partial $m g c 2$ gene has differentiated many genotypes prevailing in Pakistan. These minor variations found in this study in mgc2 gene in same region has also been reported by previous studies (Armour et al., 2013). Similar reports have also been published from USA, Israel, and Australia (Ferguson et al., 2005). Mycoplasma gallisepticum isolates studied in current study showed 96 to $98 \%$ similarity to ts- 11 vaccinal strain (KC247898) of M. gallisepticum while F strain (KC247897) has 93 to $94 \%$ similarity. A whole genome sequencing is required for detail study of nature of existing wild type strain in Pakistan. It will help us to understand that why the infection due to M. gallisepticum is prevailing in the field because the vaccine against Mycoplasmosis has been using from several decades in Pakistan. Dissimilarity of local wild type isolates from $F$ strain (vaccine strain) also suggests unsuccessful replacement of wild type stain with vaccine strain in field which may be due to improper vaccination or storage.

\section{Conclusion}

To sum up this study, prevalence of $M$. gallisepticum is high in both Rawalpindi and Abbottabad districts of Pakistan in all breeds of poultry. This study suggests the involvement of $M$. gallisepticum in CRD infections in poultry. To control infection of M. gallisepticum in poultry industry, a strict biosecurity measures should be taken in all poultry farms and a hygienic environment should be maintained in the farms. Further, a countrywide surveillance should be conducted which will help to control CRD in poultry and economic losses in the industry.

\section{Acknowledgements}

Thanks to PAK-USA Science and Technology Cooperation program International Collaborative Research Project \# 335 "Characterization of M. gallisepticum isolates in Pakistan and their use in production of indigenous diagnostic antigen and bacterin" funded by National Science Academies, USA through HEC, Islamabad, and Department of Pathobiology and Veterinary Science, University of Connecticut, Storrs, CT, USA.

\section{References}

ARMOUR, N.K., LAIBINIS, V.A., COLLETT, S.R. and FERGUSON-NOEL, N., 2013. The development and application of a Mycoplasma gallisepticum sequence database. Avian Pathology, vol. 42, no. 5, pp. 408-415. http://dx.doi.org/10.1080/03079457.2013.819 486. PMid:23889487.

BUCHALA, F., ISHIZUKA, M., MATHIAS, L., BERCHIERI JÚNIOR, A., CASTRO, A., CARDOSO, A. and KANASHIRO, A., 2006. Detecção de resposta sorológica contra Mycoplasma em aves de criatórios de "fundo de quintal" próximos a explorações comerciais do estado de São Paulo. Arquivos do Instituto Biológico, vol. 73, no. 2, pp. 143-148.

BUIM, M.R., METTIFOGO, E., TIMENETSKY, J., KLEVEN, S. and FERREIRA, A.J.P., 2009. Epidemiological survey on Mycoplasma gallisepticum and M. synoviae by multiplex PCR in commercial poultry. Pesquisa Veterinária Brasileira, vol. 29, no. 7, pp. 552556. http://dx.doi.org/10.1590/S0100-736X2009000700009.

DELANEY, N.F., BALENGER, S., BONNEAUD, C., MARX, C.J., HILL, G.E., FERGUSON-NOEL, N., TSAI, P., RODRIGO, A. and EDWARDS, S.V., 2012. Ultrafast evolution and loss of CRISPRs following a host shift in a novel wildlife pathogen, Mycoplasma gallisepticum. PLOS Genetics, vol. 8, no. 2, e1002511. http://dx.doi.org/10.1371/ journal.pgen.1002511. PMid:22346765. 
EMAM, M., HASHEM, Y.M., EL-HARIRI, M. and EL-JAKEE, J., 2020. Detection and antibiotic resistance of Mycoplasma gallisepticum and Mycoplasma synoviae among chicken flocks in Egypt. Veterinary World, vol. 13, no. 7, pp. 1410-1416. http://dx.doi org/10.14202/vetworld.2020.1410-1416. PMid:32848318.

FEBERWEE, A., MEKKES, D., DE WIT, J., HARTMAN, E. and PIJPERS, A., 2005. Comparison of culture, PCR, and different serologic tests for detection of Mycoplasma gallisepticum and Mycoplasma synoviae infections. Avian Diseases, vol. 49, no. 2, pp. 260-268. http://dx.doi.org/10.1637/7274-090804R. PMid:16094832.

FERGUSON, N.M., HEPP, D., SUN, S., IKUTA, N., LEVISOHN, S., KLEVEN, S.H. and GARCÍA, M., 2005. Use of molecular diversity of Mycoplasma gallisepticum by gene-targeted sequencing (GTS) and random amplified polymorphic DNA (RAPD) analysis for epidemiological studies. Microbiology, vol. 151, no. 6, pp. 18831893. http://dx.doi.org/10.1099/mic.0.27642-0. PMid:15941996.

GARCÍA, M., IKUTA, N., LEVISOHN, S. and KLEVEN, S., 2005. Evaluation and comparison of various PCR methods for detection of Mycoplasma gallisepticum infection in chickens. Avian Diseases, vol. 49, no. 1, pp. 125-132. http://dx.doi.org/10.1637/72610812204R1. PMid:15839425.

GHARAIBEH, S. and AL ROUSSAN, D., 2007. The use of molecular techniques in isolation and characterization of Mycoplasma gallisepticum from commercial chickens in Jordan. International Journal of Poultry Science, vol. 7, no. 1, pp. 28-35. http://dx.doi. org/10.3923/ijps.2008.28.35.

GRODIO, J.L., DHONDT, K.V., O'CONNELL, P.H. and SCHAT, K.A., 2008. Detection and quantification of Mycoplasma gallisepticum genome load in conjunctival samples of experimentally infected house finches (Carpodacus mexicanus) using real-time polymerase chain reaction. Avian Pathology, vol. 37, no. 4, pp. 385-391. http://dx.doi.org/10.1080/03079450802216629. PMid:18622854.

KHALIFA, K.A., SIDAHMED ABDELRAHIM, E., BADWI, M. and MOHAMED, A.M., 2013. Isolation and Molecular Characterization of Mycoplasma gallisepticum and Mycoplasma synoviae in Chickens in Sudan. Journal of Veterinary Medicine, vol. 2013, pp. 2013. http://dx.doi.org/10.1155/2013/208026. PMid:26464902.

KLEVEN, S., 2008. Control of avian mycoplasma infections in commercial poultry. Avian Diseases, vol. 52, no. 3, pp. 367-374. http://dx.doi.org/10.1637/8323-041808-Review.1. PMid:18939621.

LOOLMANI, F., POURBAKHSH, S., BANANI, M. and CHARKHKAR, S., 2014. Phylogenetic analysis of $m g c 2$ gene of Mycoplasma gallisepticum isolates from broiler breeder flocks in Tehran province, Iran. European Journal of Zoological Research, vol. 3 , no. 2, pp. 37-42.

LUCIANO, R., CARDOSO, A., STOPPA, G., KANASHIRO, A., DE CASTRO, A. and TESSARI, E., 2011. Comparative study of serological tests for Mycoplasma synoviae diagnosis in commercial poultry breeders. Veterinary Medicine International, vol. 2011, pp. 2011. http://dx.doi.org/10.4061/2011/304349. PMid:21547263.
MAROIS, C., DUFOUR-GESBERT, F. and KEMPF, I., 2001. Molecular differentiation of Mycoplasma gallisepticum and Mycoplasma imitans strains by pulsed-field gel electrophoresis and random amplified polymorphic DNA. Journal of Veterinary Medicine, Series B, vol. 48, no. 9, pp. 695-703. http://dx.doi.org/10.1046/j.14390450.2001.00496.x. PMid:11765805.

MCMULLIN, P., 2004. A pocket guide to poultry health and disease. Sheffield: 5M Enterprises Ltd.

MUCH, P., WINNER, F., STIPKOVITS, L., ROSENGARTEN, R. and CITTI, C., 2002. Mycoplasma gallisepticum: influence of cell invasiveness on the outcome of experimental infection in chickens. FEMS Immunology and Medical Microbiology, vol. 34, no. 3, pp. 181-186. http://dx.doi.org/10.1111/j.1574-695X.2002. tb00622.x. PMid:12423769.

NASCIMENTO, E.R., PEREIRA, V., NASCIMENTO, M. and BARRETO, M., 2005. Avian mycoplasmosis update. Brazilian Journal of Poultry Science, vol. 7, no. 1, pp. 1-9. http://dx.doi.org/10.1590/ S1516-635X2005000100001.

OSMAN, K., ALY, M., AMIN, Z. and HASAN, B., 2009. Mycoplasma gallisepticum: an emerging challenge to the poultry industry in Egypt. Revue Scientifique et Technique, vol. 28, no. 3, pp. 10151023. http://dx.doi.org/10.20506/rst.28.3.1940. PMid:20462158.

PRIYA, K. and MADHAVAN, H., 2002. Diagnostic value of enzyme linked immuno-sorbent assay for cytomegalovirus disease. Journal of Postgraduate Medicine, vol. 48, no. 3, pp. 176-178. PMid:12432189.

RAUF, M., CHAUDHARY, Z., YOUNUS, M., ANJUM, A., ALI, M., AHMAD, A. and KHAN, M., 2013. Identification of Mycoplasma gallisepticum by polymerase chain reaction and conventional diagnostics from white leghorn layer flocks. JAPS. Journal of Animal and Plant Sciences, vol. 23, no. 2, pp. 393-397.

SILVA, R., SILVA, I., JESUS, M., FERNANDES, M., OLIVEIRA, F. and EVÊNCIO-NETO, J., 2021. Co-relationship between Escherichia coli in broiler cellulitis and liver lesions. Brazilian Journal of Biology = Revista Brasileira de Biologia, vol. 81, no. 3, pp. 714-718. http://dx.doi.org/10.1590/1519-6984.230243.

TAMURA, K., PETERSON, D., PETERSON, N., STECHER, G., NEI, M. and KUMAR, S., 2011. MEGA5: molecular evolutionary genetics analysis using maximum likelihood, evolutionary distance, and maximum parsimony methods. Molecular Biology and Evolution, vol. 28, no. 10, pp. 2731-2739. http://dx.doi.org/10.1093/molbev/ msr121. PMid:21546353.

WAITES, K.B. and TALKINGTON, D.F., 2004. Mycoplasma pneumoniae and its role as a human pathogen. Clinical Microbiology Reviews, vol. 17, no. 4, pp. 697-728. http://dx.doi.org/10.1128/ CMR.17.4.697-728.2004. PMid:15489344.

YOUNI, G., ABDELGAWAD, R.H., ELKENANY, R. and GLAL, A., 2018. Molecular identification and sequencing of Mycoplasma gallisepticum recovered from broilers in Egypt. Pakistan Journal of Biological Sciences, vol. 21, no. 5, pp. 253-261. http://dx.doi. org/10.3923/pjbs.2018.253.261. 